\title{
The (FTO) gene polymorphism is associated with metabolic syndrome risk in Egyptian females: a case- control study
}

\author{
Mina S. Khella ${ }^{1}$, Nadia M. Hamdy ${ }^{1}$, Ashraf I. Amin² and Hala O. El-Mesallamy ${ }^{1 *}$
}

\begin{abstract}
Background: Variations within fat mass and obesity associated (FTO) gene had crosstalk with obesity risk in European and some Asian populations. This study was designed to investigate FTO rs9939609 association with metabolic syndrome (MetS) as well as biochemical parameters as plasma glucose, serum triacylglycerol (TAG), total cholesterol (TC) and transaminases enzymes in Arab female population from Egypt.

Methods: In order to achieve that, FTO gene rs9939609 (A < T) was genotyped using TaqMan SNP Genotyping Assay in a total of 197 females which were enrolled in this study. Fasting levels of serum insulin, lipid profile and plasma glucose, in addition to liver transaminases were measured. The association between the genotype distribution and MetS risk was evaluated using Chi-square and logistic regression tests in a case-control design under different genetic models.

Results: The association of genotype distribution with MetS was significant $(X 2=8.6 / P=0.014)$ with an increased odds ratio under dominant model $(\mathrm{OR}=1.97, P=0.029$ and $95 \% \mathrm{C} . \mathrm{I}=1.07-3.6)$ and recessive model $(\mathrm{OR}=2.95$, $P=0.017$ and $95 \% C . I=1.22-7.22)$. Moreover, $(A A)$ subjects showed significant lower HDL-C levels $(P=0.009)$ when compared to (TT) ones. In addition, interestingly subjects with (AA) genotype have significantly higher ALT levels $(P=0.02)$ that remained significant after correction of major confounders as body mass index and serum triacylglycerols but not after conservative Bonferroni adjustment.

Conclusions: The present study shows for first time that FTO gene rs9939609 is genetic risk factor for metabolic syndrome in Egyptian population which may help in understanding the biology of this complex syndrome and highlighted that this association may be through HDL-C component. The association of this genetic polymorphism with ALT levels needs to be studied in other populations with larger sample size.
\end{abstract}

Keywords: FTO, Obesity, SNP, T2DM, Alt, HDL-c, Metabolic syndrome, Serum lipids

\section{Background}

Metabolic syndrome (MetS) is considered a major risk factor for cardiovascular diseases and stroke [1] in both developing and developed countries $[2,3]$. The central obesity and type 2 diabetes mellitus (T2DM) are considered the major endophenotypes of MetS which are inheritable and genetically based [4-6]. Interestingly, Egypt had the highest mean female BMI in developing countries and even exceeded USA [7]. In Egypt, 22\% of

\footnotetext{
*Correspondence: hala_elmosalamy@hotmail.com

'Biochemistry Department, Faculty of Pharmacy, Ain Shams University,

African Union Organization Street, Abbassia, Cairo 11566, Egypt

Full list of author information is available at the end of the article
}

men while $48 \%$ of women were obese according to 2010 WHO estimate. The Middle East and North Africa Region are considered to have the highest prevalence of diabetes at $10.9 \%$ [8]. The prevalence of MetS in Egyptian females has been reached about $45.8 \%$ [9]. The FTO (fat mass- and obesity-associated) gene is a good candidate gene for T2DM and MetS, since its possible link to obesity with genome wide association study based evidence [10]. In addition, human FTO gene (16q12.2) shows ubiquitous expression in adult and fetal tissues with the most significant high expression in hypothalamus [10] linking the FTO protein function with control of energy state [11]. FTO protein is one of the non- 
heme dioxygenase superfamily, which demethylate nucleic acids in a 2- oxoglutarate-dependent manner [11]. Despite several studies showed association of FTO gene polymorphism with obesity in different populations mainly of European descent [12-16], this came in contrast with other studies in which the FTO polymorphisms do not associate with BMI or obesity risk in consistent manner as in many populations with different ethnicity [16-19]. Moreover, The association of FTO with T2DM is still inconclusive [20]. The first intronic FTO variant rs9939609 was selected specifically in this study as it depicted the highest genotyping success rate among other obesity risk SNPs and has strong genome wide association evidence with obesity [10]. Furthermore, it is highly possible that this variant, even it is not the true functional variant, is in linkage disequilibrium with true functional ones either within FTO gene or nearby genes [16].

Therefore, this study was designed to investigate the association of FTO gene rs9939609 with metabolic syndrome and its endophenotypes in Arab female population from Egypt.

\section{Methods}

\section{Study population}

A total of random unrelated 197 subjects were studied. 92 with MetS were recruited from National Diabetes Institute - Cairo - Egypt versus 105 controls without MetS. The cases and controls were carefully chosen according the IDF definition of metabolic syndrome [21]. The true selection factors include obesity anthropometric measures (waist circumference $\geq 80 \mathrm{~cm}$ and BMI $>30 \mathrm{~kg} / \mathrm{m}$ ) plus any two of the following: blood glucose level (Fasting plasma glucose $\geq 100 \mathrm{mg} / \mathrm{dl}$ or previously diagnosed Type 2 diabetes), HDL-C $(<50 \mathrm{mg} / \mathrm{dl}$ or specific treatment for this lipid abnormality) and triacylglycerol $(\geq 150 \mathrm{mg} / \mathrm{dl}$ or specific treatment for this lipid abnormality). All participants were subjected to full history and clinical data collection including blood pressure and anthropometric measures. There was a complete medical evaluation for each case with provided informed consent prior to inclusion in the study. Subjects diagnosed with severe acute infections, viral hepatitis, any endocrine disturbances or administrating sex hormones or corticosteroids for long period were excluded. All diabetic patients received only oral hypoglycemic drugs (metformin and sulfonyl urea agents) and no insulin and there was no statistical difference among patients regarding treatment agents. The initial population number was 207 females from which 10 females were excluded due to presence of liver anomaly. Since the MetS is a complex disease, the cases and controls were chosen carefully to minimize the effects of other non-genetic risk factors and were matched for dietary habits and exercise levels through asked questionnaire including dietary habits and exercising levels (the questionnaire included questions about the diet preference and whether it is carbohydrate rich, protein rich, vegetable rich or balanced one and results expressed as number and percentage and there was no significant difference between the cases and controls where the most of them used to eat carbohydrate rich diet with little protein and vegetables. Regarding the exercise levels, they were asked in the questionnaire in terms of exercising hours per day and there was also non-significant difference. In addition, any control with history of childhood obesity was excluded. Moreover, the age difference between the cases and controls was considered in the analysis of results and adjusted in all statistical tests. The Ethical Committee both of Faculty of Pharmacy, Ain Shams University, Cairo, Egypt and the National Diabetes Institute approved this study. Moreover, the study was performed in adherence to the Declaration of Helsinki Guidelines.

\section{Blood sampling}

Whole blood samples (7-10 ml each) were drawn in the early morning after an overnight fasting period of at least $12 \mathrm{~h}$. Blood Samples were collected in separate vacutainer tubes (BD Diagnostics, Franklin Lakes, NJ, USA): one containing disodium-ethlenediamine tetra-acetic acid (EDTA) for whole blood collection $(3 \mathrm{ml})$ required for DNA extraction. A second plain vacutainer was used for serum collection that was divided into aliquots for measuring lipid profile, aminotransferases and fasting insulin. The third vacutainer was fluoride containing one for collecting plasma used for measuring fasting plasma glucose. Glucose and lipids profile parameters were assayed immediately; whereas, other aliquots were immediately frozen at $\left(-80^{\circ} \mathrm{C}\right)$ until subsequent assays were performed.

\section{Anthropometric and biochemical measurements}

Anthropometric measurements included body mass index (BMI) $\left(\mathrm{Kg} / \mathrm{m}^{2}\right)$ and waist circumference (WC) $\mathrm{cm}$. Non stretchable measuring tape was used to measure waist for the subjects while they are standing in erect relaxed position.

Biochemical measurements included plasma glucose was determined by using Dimension RxL analyzer (Dade Behring, Newark, DE) automated biochemistry analyzer. Serum total cholesterol (TC), triacylglycerol (TAG), highdensity lipoprotein (HDL) cholesterol, aspartate aminotransferase (AST) and alanine aminotransferase (ALT) were determined by enzymatic methods using autoanalyser (Beckman synchron cx systems). Low-density lipoprotein (LDL) cholesterol was calculated by the Friedewald formula [22]. Serum insulin was measured using commercially available ELISA kit (Immunospec ${ }^{\bullet}$ kit, provided from Immunospec Corporation, Canoga Park, CA, USA). Homeostasis model assessment (HOMA-IR) calculated as: 
[(FBG X fasting insulin)/405] [23] and Quantitative insulin sensitivity check index (QUICKI) calculated as: 1/[log FI $(\mu \mathrm{IU} / \mathrm{ml})+\log$ FBG $(\mathrm{mg} / \mathrm{dl})][24]$ were used as a measure of insulin resistance.

\section{Genotyping}

Whole Blood DNA was extracted using QIAamp DNA Mini Kit protocol (QIAGEN, Santa Clarita, CA). The extracted DNA was stored at $-80{ }^{\circ} \mathrm{C}$ until used for genotyping assay. FTO gene genotyping rs9939609(A < T) was performed by TaqMan SNP Genotyping Assays (ABI; Applied Biosystems international, Foster City, CA) and using Real-Time PCR System (The Applied Biosystems ${ }^{\circ}$ Step One Plus $\left.{ }^{\mathrm{ru}}\right) .10 \%$ selections of the samples were re-genotyped with $100 \%$ concordance to assure genotyping reproducibility.

\section{Statistical analysis}

Statistical analyses were performed using windows based Statistical Package for Social Sciences $\left(\mathrm{SPSS}^{\circ}\right)$ computer database version 17.0 and Microsoft Excel $^{\circ}$ version 2010.

Data were described as (Mean $\pm \mathrm{SD}$ ) for numeric variables, or median and range for numeric nonparametric variables, and number and percentage (\%) for categorical variables.

The difference between the groups was analyzed using an independent Student's $t$-test (for numeric parametric variables) and Mann-Whitney's $U$-test (for numeric nonparametric variables) in case of only two groups. Comparisons between the 3 groups with respect to normally distributed numeric variables were done using the oneway analysis of variance (ANOVA). For significant tests, Bonforreni post hoc was performed for the pairwise comparisons. The Kruskal-Wallis test and the post hoc Bonferroni test were used to compare between groups regarding non-normally distributed numeric variables. Chi-square test was used to compare between the groups with respect to categorical data.

Conservative Bonferroni adjustment was applied for significant parameters (HDL-C and ALT) to avoid multiple testing error (adjusted $P$ value at 0.01 ).

Genotype and allele frequency distributions were compared with the $\left(\mathrm{x}^{2}\right)$ test and Hardy-Weinberg equilibrium was computed using an online calculator [25].

Logistic regression was performed to evaluate associations of rs 9,939,609 SNP with risk of MetS by calculating the odds ratio and their adjusted values for age with their 95\% confidence interval and corresponding $p$-value.

Multiple regression model was set to study the association of FTO polymorphism with ALT levels after correction of $\mathrm{BMI}$ and serum triglycerides.

$P$-values of $<0.05$ were considered significant. The power of study was calculated and reached nearly $70 \%$ taking significance level at 0.05 , disease prevalence $48 \%$, minor allele frequency 0.39 and average odds at 1.5 based on an online calculator (http://csg.sph.umich.edu) [26].

\section{Results}

As shown in 'Table 1', there was significant difference in anthropometric and biochemical measurements between

Table 1 Characteristics of MetS cases $(n=92)$ and controls $(n=105)$

\begin{tabular}{|c|c|c|c|}
\hline Characteristic & MetS cases $(n=92)$ & Controls $(n=105)$ & $p$ \\
\hline Age, years, mean \pm S.D & $45.33 \pm 9.56$ & $44.74 \pm 9.67$ & $0.672^{c}$ \\
\hline $\mathrm{BMI}, \mathrm{Kg} / \mathrm{m}^{2}$, mean $\pm \mathrm{S} . \mathrm{D}$ & $37.64 \pm 5.7$ & $26.07 \pm 5.4$ & $<0.001^{\mathrm{a}}$ \\
\hline Waist $(\mathrm{cm})$, mean \pm S.D & $119.76 \pm 10.96$ & $89.68 \pm 13.87$ & $<0.001^{\mathrm{a}}$ \\
\hline $\mathrm{TC}(\mathrm{mg} / \mathrm{dl})$, mean $\pm \mathrm{S} . \mathrm{D}$ & $182.12 \pm 44.52$ & $165.42 \pm 22.74$ & $0.001^{\mathrm{a}}$ \\
\hline $\mathrm{TAG}(\mathrm{mg} / \mathrm{dl})$, mean \pm S.D & $177.45 \pm 84.06$ & $110.06 \pm 33.25$ & $<0.001^{\mathrm{a}}$ \\
\hline $\mathrm{HDL}-\mathrm{C}(\mathrm{mg} / \mathrm{dl})$, mean $\pm \mathrm{S} . \mathrm{D}$ & $38.51 \pm 9.33$ & $44.76 \pm 8.07$ & $<0.001^{\mathrm{a}}$ \\
\hline $\mathrm{LDL}-\mathrm{C}(\mathrm{mg} / \mathrm{dl})$, mean $\pm \mathrm{S} . \mathrm{D}$ & $108.11 \pm 39.44$ & $98.58 \pm 20.31$ & $0.038^{a}$ \\
\hline FPG (mg/dl), median(min-max) & $161(64-361)$ & $89(60-323)$ & $<0.001^{b}$ \\
\hline $\mathrm{FSI}(\mu \mathrm{IU} / \mathrm{mL}), \operatorname{median}(\min -\max )$ & $13.39(2.9-30.3)$ & $8.5(1-30)$ & $<0.001^{b}$ \\
\hline HOMA-IR, median(min-max) & $4.48(0.77-20.46)$ & $1.9(0.2-23.93)$ & $<0.001^{\mathrm{b}}$ \\
\hline QUICKI, mean \pm S.D & $0.31 \pm 0.04$ & $0.35 \pm 0.05$ & $<0.001^{\mathrm{a}}$ \\
\hline \multicolumn{4}{|l|}{ FTO (rs9939609) } \\
\hline$\Pi$ T, n(\%) & $24(26.1)$ & $43(41)$ & \\
\hline AT, n(\%) & $50(54.4)$ & $54(51.4)$ & \\
\hline $\mathrm{AA}, \mathrm{n}(\%)$ & $18(19.5)$ & $8(7.6)$ & $0.014^{c}$ \\
\hline
\end{tabular}

Values are mean \pm SD for parametric variables or median (range) for non-parametric variables. BMI Body mass index, WC Waist circumference, T.C Total cholesterol, TAG Triacylglycerol, HDL-C High density lipoprotein-cholesterol, LDL-C Low density lipoprotein-cholesterol, FPG Fasting plasma glucose, FSI Fasting serum insulin ${ }^{a}$ Independent T- test, two-sided $p$ value $>0.05$ non-significant

${ }^{b}$ Mann-Whitney $\mathrm{U}$ test, two sided $p$ value $>0.05$ non-significant

${ }^{c} \mathrm{Chi}$-square test, two-sided $p$ value $>0.05$ non-significant 
the study groups. The BMI, waist circumference, plasma glucose, HOMA-IR, TAG, TC and LDL-C were significantly higher, while HDL-C level was lower in the group with MetS vs control group.

In the whole population the distribution of genotype for rs 9,939,609 variant were $34 \% \mathrm{TT}, 52.8 \% \mathrm{TA}$ and $13.2 \%$ AA. In the MetS group, the genotype distribution was $26.1 \% \mathrm{TT}, 54.4 \%$ TA and $19.5 \%$ AA vs $41 \%$ TT, $51.4 \% \mathrm{TA}$ and $7.6 \% \mathrm{AA}$ in the control group, as shown in 'Table 2'. This came in agreement with Hardy-Weinberg equilibrium $(P>0.05)$ in the whole population and in the individual study groups. The overall minor allelic frequency (MAF) of the risk allele A of FTO gene rs9939609 was (0.39).

As depicted in 'Table 2', the dominant genetic model showed a 1.97 -fold increase in the odds of MetS $(95 \%$ C.I $=1.07-3.6, p=0.029)$. Under recessive genetic mode, the AA genotype showed a 2.95-fold increase in the odds of MetS (95\% C.I $=1.22-7.22, p=0.017$ ).

There was no significant difference in both anthropometric and biochemical measurements of the whole population among the different genotypes at all models (additive, dominant, and recessive) except for ALT and HDL-C levels. Regarding ALT, it was significantly higher in AA carriers $(P=0.02)$, as shown in 'Table 3'. The association remained significant after correction of BMI and serum TAG. However, this association was abolished after applying the conservative Bonferroni adjustment for multiple testing. Regarding HDL-C levels, the AA genotype showed significantly lower levels $(P=0.009)$ and interestingly it remained significant after conservative Bonferroni adjustment.

\section{Discussion}

This is the first study to investigate the allele frequency and genotype distribution of FTO gene rs9939609 and its association with MetS including its endophenotypes of serum lipids in Egyptian female population. The overall MAF (A) in our study was (0.39) which is very similar to some European population as that of adult population from Spain which was (0.39) [12] and slightly lower than that of Italian population which was (0.48) [13]. Regarding Asian ancestry, a remarkably different MAF appeared which was (0.2) in

Table 2 Association between FTO genotypes and MetS risk

\begin{tabular}{|c|c|c|c|}
\hline & $\mathrm{OR}^{\mathrm{a}}$ & $95 \% \mathrm{Cl}$ & $p$ \\
\hline \multicolumn{4}{|c|}{ Dominant Genetic Model } \\
\hline$\pi$ & Reference & Reference & \\
\hline AT/AA & 1.97 & $1.07,3.6$ & 0.029 \\
\hline \multicolumn{4}{|c|}{ Recessive Genetic Model } \\
\hline $\mathrm{AT} / \mathrm{TT}$ & Reference & Reference & \\
\hline AA & 2.95 & $1.22,7.22$ & 0.017 \\
\hline
\end{tabular}

Japanese population [27], (0.19) in Pakistani females [28] and (0.12) in Chinese population [29]. Our allele frequency results were also higher than that of black African population which was (0.35) [30] and slightly lower than the Brazilian one which was (0.435) [31] .

Despite MAF similarity in the current study with some European population, the genotypes distribution in our study groups was unique. In addition, our study revealed a positive association between $F T O$ variant and MetS for the first time in Egyptian Arab female population. AlAttar et al. (2008) reported in non-Caucasian population an association between rs9939609 FTO SNP and MetS risk that was dependent on obesity and HDL-C components. Moreover, the association was more prominent in men [32]. Our study declared association with MetS in cohort of Arab Egyptian Caucasian females that may be dependent partially on the association with lowered HDL-C levels. In agreement with our study, another positive association was observed in Han Chinese between the FTO SNP rs8047395 and MetS but with no significant associations with any endophenotypes of MetS [33]. Another important strength point of our study is that the cases and controls were carefully matched in other non-genetic risk factors of the MetS like the dietary habits and exercise levels which sheds more light on the impact of genetic factors. Regarding the association of FTO variation with lipid profile levels, our study showed non-significant association except for HDL-C levels. This came in contrast with other studies which showed non-significant association with all lipid profile $[29,34]$ or showed association with elevated triglycerides levels $[35,36]$. However, it came in agreement with other studies depicted reduced HDL-c levels [36-38]. Moreover, the associations in other studies were more prominent in men $[32,39]$. Subjects with AA genotype have higher BMI and WC compared to TA and TT carriers, however this difference didn't reach statistical significance, may be due to relatively small sample size and different effect size in case of BMI. This is in agreement with three previous studies that didn't detect association of rs9939609 FTO polymorphism with BMI and/or WC in a similar sample size $[19,35,40]$. In addition, there was association of FTO polymorphism with MetS in our study under both the dominant and recessive models unlike other studies like the one carried on Italian male and female population in which only the TA genotype showed association [41] and the one carried among Tunisian population [42]. Xu et al. (2014) showed significant association of FTO variations with some metabolic parameters under recessive model and even in higher sample size of our study [43]. We hypothesized that the association under recessive model was apparent here in our study may be due to association of (AA) subjects with lowered HDL-C levels compared to (TT) subjects. Those 
Table 3 association between FTO (rs9939609) polymorphism and Clinical characteristics of subjects

\begin{tabular}{|c|c|c|c|c|}
\hline \multirow[t]{2}{*}{ Characteristics } & \multicolumn{3}{|c|}{ FTO (rs9939609) Genotypes } & \multirow[t]{2}{*}{$P$} \\
\hline & $\Pi(n=67)$ & $\operatorname{AT}(n=104)$ & $\mathrm{AA}(n=26)$ & \\
\hline Age, years, mean $\pm S . D$ & $46.3 \pm 8.6$ & $44.02 \pm 9.8$ & $45.65 \pm 10.7$ & $0.29^{a}$ \\
\hline $\mathrm{BMI}, \mathrm{Kg} / \mathrm{m}^{2}$, mean $\pm \mathrm{S} . \mathrm{D}$ & $31 \pm 8$ & $31.37 \pm 8.2$ & $33.1 \pm 7.2$ & $0.51^{\mathrm{a}}$ \\
\hline Waist $(\mathrm{cm})$, mean $\pm S . D$ & $103.2 \pm 20.2$ & $103.3 \pm 20.1$ & $106.8 \pm 16.1$ & $0.69^{\mathrm{a}}$ \\
\hline $\mathrm{TC}(\mathrm{mg} / \mathrm{dl})$, mean $\pm \mathrm{S} . \mathrm{D}$ & $178.3 \pm 33.1$ & $172.4 \pm 36.2$ & $163.4 \pm 38$ & $0.18^{a}$ \\
\hline $\mathrm{TAG}(\mathrm{mg} / \mathrm{dl})$, mean \pm S.D & $148.3 \pm 73.8$ & $138.6 \pm 71.9$ & $136 \pm 58$ & $0.62^{\mathrm{a}}$ \\
\hline $\mathrm{HDL}-\mathrm{C}(\mathrm{mg} / \mathrm{dl})$, mean $\pm \mathrm{S} . \mathrm{D}$ & $43.2 \pm 10.7$ & $42.2 \pm 8$ & $37 \pm 8.5$ & $0.01^{\mathrm{a}}$ \\
\hline $\mathrm{LDL}-\mathrm{C}(\mathrm{mg} / \mathrm{dl})$, mean $\pm \mathrm{S} . \mathrm{D}$ & $105.4 \pm 29.7$ & $102.5 \pm 32.7$ & $99.3 \pm 27.7$ & $0.67^{\mathrm{a}}$ \\
\hline FPG (mg/dl), median(min-max) & 108(69-323) & $100.5(60-361)$ & $138.5(76-350)$ & $0.2^{b}$ \\
\hline $\mathrm{FSI}(\mu \mid \mathrm{U} / \mathrm{mL}), \operatorname{median}(\min -\max )$ & $10.5(2.4-30)$ & $9.73(1-30.3)$ & $12.2(2.9-29.3)$ & $0.59^{b}$ \\
\hline HOMA-IR,median(min-max) & $3.1(0.6-23.9)$ & $2.4(0.2-20.45)$ & $3.6(1.29-20.46)$ & $0.28^{b}$ \\
\hline QUICKI, mean \pm S.D & $0.33 \pm 0.042$ & $0.34 \pm 0.06$ & $0.32 \pm 0.034$ & $0.11^{\mathrm{a}}$ \\
\hline AST(IU/mL), median(min-max) & $15(4-53)$ & $12.5(4-60)$ & $17(8-58)$ & $0.19^{b}$ \\
\hline ALT(IU/mL), median(min-max) & $14(4-60)$ & $11(4-57)$ & $15.5(6-58)$ & $0.02^{b}$ \\
\hline
\end{tabular}

BMI Body mass index, WC Waist circumference, T.C Total cholesterol, TAG Triacylglycerol, HDL-C High density lipoprotein-cholesterol, LDL-C Low density lipoprotein-cholesterol, FPG Fasting plasma glucose, FSI Fasting serum insulin

${ }^{a}$ one way ANOVA test, two-sided $p$ value $>0.05$ non-significant

${ }^{\mathrm{b}}$ Kruskal-Wallis test, two-sided $p$ value $>0.05$ non-significant

differences may be due to different ethnic group, different sample size, different study design or different population age.

The FTO association with MetS may be related to association with obesity [10], T2DM [44] and/or lipid abnormalities [32, 35]. The exact mechanism by which FTO protein is linked to obesity and T2DM is still completely unknown. Being highly expressed in the hypothalamus, FTO plays a key role in energy homeostasis [11]. Genetic variants of FTO were associated with increased energy intake $[40,45,46]$. Based on bioinformatics and in vitro studies FTO encodes for demethylase enzyme for DNA and RNA nucleotides especially RNA single strands [11, 47]. Changes in the DNA methylation state are significantly associated with many pathological diseases and abnormalities including obesity $[48,49]$. For example, it is interesting that Indian children obesity was affected by vitamin B12 and folate maternal levels [50] indicating that methylation state plays a key role in risk contribution for obesity and related disorders [51]. This highlights that FTO link with obesity could be mediated by epigenetic changes in DNA methylation [52]. Moreover, the FTO plays a key role in the regulation of food intake through its function of sensing the levels of amino acids in the hypothalamus [53] which is known to affect orexigenic and anorexigenic pathways [54]. Very recently, it was shown that genetic variants within FTO gene are linked functionally to another distant gene called IRX3 which may link the association of FTO SNPs with both obesity and T2DM $[55,56]$. Moreover, our study suggests for the first time an association of FTO polymorphism with high
ALT levels that seems to be BMI independent, though the association was no longer statistically significant when corrected for multiple comparisons. Wu et al., 2010 hypothesized that the intronic genetic variants like rs9939609 affected the expression of FTO protein which may modulate adipogenesis in adipose tissue [57]. Interestingly nonalcoholic fatty liver disease (NAFLD) rat model in which the FTO overexpressed in liver showed increased oxidative stress and lipogenesis and was associated also with increased ALT levels [58]. This suggests an association of FTO genetic variation with ALT might be mediated through NAFLD, though participants with overt liver disease were excluded from our study. Another possibility is that FTO contributes directly to the regulation of hepatic metabolism [59]. Very recently, Guan et al. (2014) showed a significant association between ALT level and variants of some obesity-susceptible genes, but not FTO, either dependent or independent of BMI [60]. As a result this association with ALT needs to be validated in other populations with large sample size. We acknowledge the relative small sample size, however we are taking an advantage of the high frequency of the variant understudy in the Egyptian population, as reported to be 39\% with unique distribution in the control and cases group which improves the power of study. Hopefully, our reported findings act as base for further future studies with larger sample size.

\section{Conclusions}

this study highlighted for the first time a possible link between the FTO homozygous variant (AA) and the risk 
for MetS in Arab Egyptian female population that may be mediated through HDL-C lowered levels. Moreover, our study suggests a novel BMI and TAG-independent association of FTO genetic variation with elevated ALT levels that needs to be validated in other large sample sizes. We believe that this study hopefully helps in clarifying the pathophysiology and etiology of metabolic syndrome. Moreover, it will aid in early predicting those with high risk of developing metabolic syndrome which will result in better personalized strategies of treatment, nutrition or prevention. In addition our study, by linking FTO polymorphism with metabolic syndrome highlights the possible link between the FTO polymorphism with cardiovascular disorders.

\section{Abbreviations \\ ALT: Alanine aminotransferase; AST: Aspartate aminotransferase; BMI: Body mass index; FPG: Fasting plasma glucose; FSI: Fasting serum insulin; FTO: Fat mass and obesity associated; HDL-C: High density lipoprotein- cholesterol; LDL-C: Low density lipoprotein-cholesterol; MetS: Metabolic syndrome; SNP: Single nucleotide polymorphism; T.C: Total cholesterol; T2DM: Type 2 diabetes mellitus; TAG: Triacylglycerol; WC: Waist circumference}

\section{Acknowledgements}

We want to express our deep appreciation to Dr. Hesham El-Hefnawy and all members of the Outpatient Clinic and Laboratory department, NIDE, for their kind help to achieve this research.

\section{Funding}

None to declare.

\section{Availability of data and materials}

The clinical raw datasets supporting our findings will be available upon request from the authors due to some patient confidentiality.

\section{Authors' contributions}

The conception and design of the work: MSK, NMH and HOE. Performed the experiments: MSK. The acquisition and interpretation of data for the work: MSK, NMH, Al A and HOE. Drafting the work or revising it critically for important intellectual content: MSK, NMH and HOE. Final approval of the version to be published: MSK, NMH, AIA and HOE. All authors read and approved the final manuscript.

\section{Ethics approval and consent to participate}

The Ethical Committee of Faculty of Pharmacy, Ain Shams University, Cairo, Egypt approved this study. Moreover, the study was performed in adherence to the Declaration of Helsinki Guidelines. There was a complete medical evaluation for each case with provided informed consent prior to inclusion in the study.

\section{Competing interest}

The authors declare that there is no conflict of interests regarding this study.

\section{Consent for publication}

Not applicable.

\section{Publisher's Note}

Springer Nature remains neutral with regard to jurisdictional claims in published maps and institutional affiliations.

\section{Author details}

'Biochemistry Department, Faculty of Pharmacy, Ain Shams University, African Union Organization Street, Abbassia, Cairo 11566, Egypt. ${ }^{2}$ Clinical Pathology and Laboratory Department, National Institute of Diabetes and Endocrinology (NIDE), Cairo, Egypt.
Received: 25 June 2017 Accepted: 8 September 2017

Published online: 16 September 2017

\section{References}

1. Grundy SM, Cleeman JI, Daniels SR, Donato KA, Eckel RH, Franklin BA, Gordon DJ, Krauss RM, Savage PJ, Smith SC Jr, Spertus JA, Costa F. Diagnosis and management of the metabolic syndrome: an American Heart Association/National Heart, Lung, and Blood Institute scientific statement. Circulation. 2005;112(17):2735-52. doi: 10.1161/circulationaha.105.169404.

2. Ekelund U, Anderssen S, Andersen LB, Riddoch CJ, Sardinha LB, Luan J, Froberg K, Brage $S$. Prevalence and correlates of the metabolic syndrome in a population-based sample of European youth. Am J Clin Nutr. 2009;89(1): 90-6. doi: 10.3945/ajcn.2008.26649.

3. Steinberger J, Daniels SR, Eckel RH, Hayman L, Lustig RH, McCrindle B, Mietus-Snyder ML. Progress and challenges in metabolic syndrome in children and adolescents: a scientific statement from the American Heart Association Atherosclerosis, Hypertension, and Obesity in the Young Committee of the Council on Cardiovascular Disease in the Young; Council on Cardiovascular Nursing; and Council on Nutrition, Physical Activity, and Metabolism. Circulation. 2009:119(4):628-47. doi: 10.1161/circulationaha.108. 191394

4. Groop L. Genetics of the metabolic syndrome. Br J Nutr. 2000;83(Suppl 1): S39-48.

5. Nemr R, Echtay A, Dashti EA, Almawi AW, Al-Busaidi AS, Keleshian SH, IraniHakime N, Almawi WY. Strong association of common variants in the IGF2BP2 gene with type 2 diabetes in Lebanese Arabs. Diabetes Res Clin Pract. 2012;96(2):225-9. doi: 10.1016/j.diabres.2011.12.026.

6. Reuter CP, Rosane De Moura Valim A, Gaya AR, Borges TS, Klinger El, Possuelo LG, Franke SI, Kmetzsch L, Vainstein MH, Pra D, Burgos MS. FTO polymorphism, cardiorespiratory fitness, and obesity in Brazilian youth. American journal of human biology : the official journal of the Human Biology Council. 2015; doi: 10.1002/ajhb.22798.

7. Martorell R, Khan LK, Hughes ML, Grummer-Strawn LM. Obesity in women from developing countries. Eur J Clin Nutr. 2000;54(3):247-52.

8. IDF (2013) IDF Diabetes Atlas.

9. Abd Elaziz KM, Gabal MS, Aldafrawy OA, Abou Seif HA, Allam MF. Prevalence of metabolic syndrome and cardiovascular risk factors among voluntary screened middle-aged and elderly Egyptians. Journal of public health (Oxford, England). 2015;37(4):612-7. doi: 10.1093/pubmed/fdu097.

10. Frayling $T M$, Timpson $N J$, Weedon $M N$, Zeggini E, Freathy RM, Lindgren CM, Perry JRB, Elliott KS, Lango H, Rayner NW, Shields B, Harries LW, Barrett JC, Ellard S, Groves CJ, Knight B, Patch A-M, Ness AR, Ebrahim S, Lawlor DA, Ring SM, Ben-Shlomo Y, Jarvelin M-R, Sovio U, Bennett AJ, Melzer D, Ferrucci L, Loos RJF, Barroso I, Wareham NJ, Karpe F, Owen KR, Cardon LR, Walker M, Hitman GA, Palmer CNA, Doney ASF, Morris AD, Smith GD, Consortium TWTCC, Hattersley AT, McCarthy MI. A common variant in the FTO gene is associated with body mass index and predisposes to childhood and adult obesity. Science. 2007:316(5826):889-94. doi: 10.1126/science. 1141634.

11. Gerken T, Girard CA, Tung Y-CL, Webby CJ, Saudek V, Hewitson KS, Yeo GSH, McDonough MA, Cunliffe S, McNeill LA, Galvanovskis J, Rorsman P, Robins P, Prieur X, Coll AP, Ma M, Jovanovic Z, Faroogi IS, Sedgwick B, Barroso I, Lindahl T, Ponting CP, Ashcroft FM, O'Rahilly S, Schofield CJ. The obesity-associated FTO gene encodes a 2-Oxoglutarate-dependent nucleic acid demethylase. Science. 2007;318(5855):1469-72. doi: 10.1126/science. 1151710.

12. Gonzalez-Sanchez UL, Zabena C, Martinez-Larrad MT, Martinez-Calatrava MJ, Perez-Barba M, Serrano-Rios M. Variant rs9939609 in the FTO gene is associated with obesity in an adult population from Spain. Clin Endocrinol. 2009;70(3):390-3. doi: 10.1111/j.1365-2265.2008.03335.x.

13. Sentinelli F, Incani M, Coccia F, Capoccia D, Cambuli VM, Romeo S, Cossu E, Cavallo MG, Leonetti F, Baroni MG. Association of FTO polymorphisms with early age of obesity in obese Italian subjects. Exp Diabetes Res. 2012;2012: 872176. doi: 10.1155/2012/872176.

14. Zhang G, Karns R, Narancic NS, Sun G, Cheng H, Missoni S, Durakovic Z, Rudan P, Chakraborty R, Deka R. Common SNPs in FTO gene are associated with obesity related anthropometric traits in an island population from the eastern Adriatic coast of Croatia. PLoS One. 2010;5(4):e10375. doi: 10.1371/ journal.pone.0010375.

15. Peeters A, Beckers S, Verrijken A, Roevens P, Peeters P, Van Gaal L, Van Hu $W$. Variants in the FTO gene are associated with common obesity in the 
Belgian population. Mol Genet Metab. 2008;93(4):481-4. doi: 10.1016/j. ymgme.2007.10.011.

16. Scuteri A, Sanna S, Chen WM, Uda M, Albai G, Strait J, Najjar S, Nagaraja R, Orru M, Usala G, Dei M, Lai S, Maschio A, Busonero F, Mulas A, Ehret GB, Fink AA, Weder AB, Cooper RS, Galan P, Chakravarti A, Schlessinger D, Cao A, Lakatta E, Abecasis GR. Genome-wide association scan shows genetic variants in the FTO gene are associated with obesity-related traits. PLOS Genet. 2007;3(7):e115. doi: 10.1371/journal.pgen.0030115.

17. Li H, Wu Y, Loos RJ, Hu FB, Liu Y, Wang J, Yu Z, Lin X. Variants in the fat mass- and obesity-associated (FTO) gene are not associated with obesity in a Chinese Han population. Diabetes. 2008;57(1):264-8. https://doi.org/10. 2337/db07-1130.

18. Horikoshi M, Hara K, Ito C, Shojima N, Nagai R, Ueki K, Froguel P, Kadowaki T. Variations in the HHEX gene are associated with increased risk of type 2 diabetes in the Japanese population. Diabetologia. 2007;50(12):2461-6. doi: 10.1007/s00125-007-0827-5.

19. Ohashi J, Naka I, Kimura R, Natsuhara K, Yamauchi T, Furusawa T, Nakazawa M, Ataka Y, Patarapotikul J, Nuchnoi P, Tokunaga K, Ishida T, Inaoka T, Matsumura Y, Ohtsuka R. FTO polymorphisms in oceanic populations. J Hum Genet. 2007;52(12):1031-5. doi: 10.1007/s10038-007-0198-2.

20. Meyre D. Is FTO a type 2 diabetes susceptibility gene? Diabetologia. 2012; 55(4):873-6. doi: 10.1007/s00125-012-2478-4.

21. Alberti KG, Zimmet $P$, Shaw J. Metabolic syndrome-a new world-wide definition. A consensus statement from the international diabetes federation. Diabetic medicine : a journal of the British Diabetic Association. 2006;23(5):469-80. doi: 10.1111/j.1464-5491.2006.01858.x.

22. Friedewald WT, Levy RI, Fredrickson DS. Estimation of the concentration of low-density lipoprotein cholesterol in plasma, without use of the preparative ultracentrifuge. Clin Chem. 1972;18(6):499-502.

23. Matthews DR, Hosker JP, Rudenski AS, Naylor BA, Treacher DF, Turner RC. Homeostasis model assessment: insulin resistance and beta-cell function from fasting plasma glucose and insulin concentrations in man. Diabetologia. 1985;28(7):412-9.

24. Katz A, Nambi SS, Mather K, Baron AD, Follmann DA, Sullivan G, Quon MJ. Quantitative insulin sensitivity check index: a simple, accurate method for assessing insulin sensitivity in humans. J Clin Endocrinol Metab. 2000;85(7): 2402-10. doi: 10.1210/jcem.85.7.6661.

25. Rodriguez S, Gaunt TR, Day INM. Hardy-Weinberg equilibrium testing of biological ascertainment for Mendelian randomization studies. Am J Epidemiol. 2009;169(4):505-14. doi: 10.1093/aje/kwn359.

26. Skol AD, Scott $L$, Abecasis GR, Boehnke M. Joint analysis is more efficient than replication-based analysis for two-stage genome-wide association studies. Nat Genet. 2006;38(2):209-13. doi: 10.1038/ng1706.

27. Hotta K, Nakata Y, Matsuo T, Kamohara S, Kotani K, Komatsu R, Itoh N, Mineo I, Wada J, Masuzaki H, Yoneda M, Nakajima A, Miyazaki S, Tokunaga K, Kawamoto M, Funahashi T, Hamaguchi K, Yamada K, Hanafusa T, Oikawa S, Yoshimatsu H, Nakao K, Sakata T, Matsuzawa Y, Tanaka K, Kamatani N, Nakamura Y. Variations in the FTO gene are associated with severe obesity in the Japanese. J Hum Genet. 2008;53(6):546-53. doi: 10.1007/s10038-0080283-1.

28. Shahid A, Rana S, Saeed S, Imran M, Afzal N, Mahmood S. Common variant of FTO gene, rs9939609, and obesity in Pakistani females. Biomed Res Int. 2013;2013:324093. doi: 10.1155/2013/324093.

29. Xi B, Shen Y, Zhang M, Liu X, Zhao X, Wu L, Cheng H, Hou D, Lindpaintner K, Liu L, Mi J, Wang X. The common rs9939609 variant of the fat mass and obesity-associated gene is associated with obesity risk in children and adolescents of Beijing, China. BMC Medical Genetics. 2010;11(1):107.

30. Hennig B, Fulford A, Sirugo G, Rayco-Solon P, Hattersley A, Frayling T, Prentice A. FTO gene variation and measures of body mass in an African population. BMC Medical Genetics. 2009;10(1):21.

31. Ramos AV, Bastos-Rodrigues $L$, Resende BA, Friedman E, Campanha-Versiani L, Miranda DM, Sarquis M, De Marco L. The contribution of FTO and UCP-1 SNPs to extreme obesity, diabetes and cardiovascular risk in Brazilian individuals. BMC Med Genet. 2012;13:101. doi: 10.1186/1471-2350-13-101.

32. Al-Attar SA, Pollex RL, Ban MR, Young TK, Bjerregaard P, Anand SS, Yusuf S, Zinman B, Harris SB, Hanley AJ, Connelly PW, Huff MW, Hegele RA. Association between the FTO rs9939609 polymorphism and the metabolic syndrome in a non-Caucasian multi-ethnic sample. Cardiovasc Diabetol. 2008;7:5. doi: 10.1186/1475-2840-7-5.

33. Wang $T$, Huang $Y$, Xiao XH, Wang DM, Diao CM, Zhang F, Xu LL, Zhang YB, Li WH, Zhang LL, Zhang Y, Sun XF, Zhang Q. The association between common genetic variation in the FTO gene and metabolic syndrome in Han Chinese. Chin Med J. 2010;123(14):1852-8.

34. Sentinelli F, Incani M, Coccia F, Capoccia D, Cambuli VM, Romeo S, Cossu E, Cavallo MG, Leonetti F, Baroni MG. Association of FTO polymorphisms with early age of obesity in obese Italian subjects. Exp Diabetes Res. 2012;2012

35. Zabena C, Gonzalez-Sanchez JL, Martinez-Larrad MT, Torres-Garcia A, Alvarez-Fernandez-Represa J, Corbaton-Anchuelo A, Perez-Barba M, SerranoRios M. The FTO obesity gene. Genotyping and gene expression analysis in morbidly obese patients. Obes Surg. 2009;19(1):87-95. doi: 10.1007/s11695008-9727-0.

36. Freathy RM, Timpson NJ, Lawlor DA, Pouta A, Ben-Shlomo Y, Ruokonen A, Ebrahim S, Shields B, Zeggini E, Weedon MN, Lindgren CM, Lango H, Melzer D, Ferrucci L, Paolisso G, Neville MJ, Karpe F, Palmer CN, Morris AD, Elliott P, Jarvelin MR, Smith GD, McCarthy MI, Hattersley AT, Frayling TM. Common variation in the FTO gene alters diabetes-related metabolic traits to the extent expected given its effect on BMI. Diabetes. 2008;57(5):1419-26. doi: 10.2337/db07-1466.

37. Doney AS, Dannfald J, Kimber CH, Donnelly LA, Pearson E, Morris AD, Palmer CN. The FTO gene is associated with an atherogenic lipid profile and myocardial infarction in patients with type 2 diabetes: a genetics of diabetes audit and research study in Tayside Scotland (go-DARTS) study. Circ Cardiovasc Genet. 2009;2(3):255-9. doi: 10.1161/circgenetics.108.822320.

38. Kring SI, Holst C, Zimmermann E, Jess T, Berentzen T, Toubro S, Hansen T, Astrup A, Pedersen O, Sorensen TI. FTO gene associated fatness in relation to body fat distribution and metabolic traits throughout a broad range of fatness. PLoS One. 2008;3(8):e2958. doi: 10.1371/journal.pone.0002958.

39. Lappalainen T, Kolehmainen M, Schwab US, Tolppanen AM, Stancakova A, Lindstrom J, Eriksson JG, Keinanen-Kiukaanniemi S, Aunola S, llanne-Parikka P, Herder C, Koenig W, Gylling H, Kolb H, Tuomilehto J, Kuusisto J, Uusitupa M. Association of the FTO gene variant (rs9939609) with cardiovascular disease in men with abnormal glucose metabolism-the Finnish diabetes prevention study. Nutrition, metabolism, and cardiovascular diseases : NMCD. 2011;21(9):691-8. doi: 10.1016/j.numecd.2010.01.006.

40. Speakman JR, Rance KA, Johnstone AM. Polymorphisms of the FTO gene are associated with variation in energy intake, but not energy expenditure. Obesity (Silver Spring, Md). 2008;16(8):1961-5. doi: 10.1038/oby.2008.318.

41. Liguori R, Labruna G, Alfieri A, Martone D, Farinaro E, Contaldo F, Sacchetti L, Pasanisi F, Buono P. The FTO gene polymorphism (rs9939609) is associated with metabolic syndrome in morbidly obese subjects from southern Italy. Molecular and cellular probes. 2014;28(4):195-9. doi: 10.1016/ J.Mcp.2014.03.004.

42. Elouej S, Belfki-Benali H, Nagara M, Lasram K, Attaoua R, Sallem OK, Kamoun I, Chargui M, Romdhane L, Jamoussi H, Turki Z, Abid A, Ben Slama C, Bahri S, Abdelhak S, Grigorescu F, Ben Romdhane H, Kefi R. Association of rs9939609 polymorphism with metabolic parameters and FTO risk haplotype among Tunisian metabolic syndrome. Metab Syndr Relat Disord. 2016;14(2):121-8. doi: 10.1089/met.2015.0090.

43. Xu Y, Ling J, Yang M, Wang H, Zhang S, Zhang X, Zhu Y. Rs7206790 And rs1 1644943 in FTO gene are associated with risk of obesity in Chinese school-age population. PLoS One. 2014;9(9):e108050. doi: 10.1371/journal. pone.0108050.

44. Hertel JK, Johansson S, Sonestedt E, Jonsson A, Lie RT, Platou CG, Nilsson PM, Rukh G, Midthjell K, Hveem K, Melander O, Groop L, Lyssenko V, Molven A, Orho-Melander M, Njolstad PR. FTO, type 2 diabetes, and weight gain throughout adult life: a meta-analysis of 41,504 subjects from the Scandinavian HUNT, MDC, and MPP studies. Diabetes. 2011;60(5):1637-44. doi: $10.2337 / \mathrm{db} 10-1340$.

45. Cecil JE, Tavendale R, Watt P, Hetherington MM, Palmer CN. An obesityassociated FTO gene variant and increased energy intake in children. $N$ Engl J Med. 2008;359(24):2558-66. doi: 10.1056/NEJMoa0803839.

46. Haupt A, Thamer C, Staiger H, Tschritter O, Kirchhoff K, Machicao F, Haring $\mathrm{HU}$, Stefan N, Fritsche A. Variation in the FTO gene influences food intake but not energy expenditure. Exp Clin Endocrinol Diabetes. 2009;117(4):1947. doi: $10.1055 / s-0028-1087176$

47. Jia G, Yang C-G, Yang S, Jian X, Yi C, Zhou Z, He C. Oxidative demethylation of 3-methylthymine and 3-methyluracil in single-stranded DNA and RNA by mouse and human FTO. FEBS letters. 2008;582(23-24):3313-9. doi: 10.1016/J. Febslet.2008.08.019.

48. Campion J, Milagro Fl, Martinez JA. Individuality and epigenetics in obesity. Obesity reviews : an official journal of the International Association for the Study of Obesity. 2009;10(4):383-92. doi: 10.1111/j.1467-789X.2009.00595.X. 
49. Javierre BM, Fernandez AF, Richter J, Al-Shahrour F, Martin-Subero Jl, Rodriguez-Ubreva J, Berdasco M, Fraga MF, O'Hanlon TP, Rider LG, Jacinto FV, Lopez-Longo FJ, Dopazo J, Forn M, Peinado MA, Carreno L, Sawalha AH, Harley JB, Siebert R, Esteller M, Miller FW, Ballestar E. Changes in the pattern of DNA methylation associate with twin discordance in systemic lupus erythematosus. Genome Res. 2010;20(2):170-9. doi: 10.1101/gr.100289.109.

50. Yajnik CS, Deshpande SS, Jackson AA, Refsum H, Rao S, Fisher DJ, Bhat DS, Naik SS, Coyaji KJ, Joglekar CV, Joshi N, Lubree HG, Deshpande VU, Rege SS, Fall $\mathrm{CH}$. Vitamin B12 and folate concentrations during pregnancy and insulin resistance in the offspring: the Pune maternal nutrition study. Diabetologia. 2008;51(1):29-38. doi: 10.1007/s00125-007-0793-y.

51. Yajnik CS, Janipalli CS, Bhaskar S, Kulkarni SR, Freathy RM, Prakash S, Mani KR, Weedon MN, Kale SD, Deshpande J, Krishnaveni GV, Veena SR, Fall CH, McCarthy MI, Frayling TM, Hattersley AT, Chandak GR. FTO gene variants are strongly associated with type 2 diabetes in south Asian Indians. Diabetologia. 2009;52(2):247-52. doi: 10.1007/s00125-008-1186-6.

52. Han Z, Niu T, Chang J, Lei X, Zhao M, Wang Q, Cheng W, Wang J, Feng Y, Chai J. Crystal structure of the FTO protein reveals basis for its substrate specificity. Nature. 2010;464(7292):1205-209. https:/www.nature.com/ nature/journal/v464/n7292/suppinfo/nature08921.html.

53. Gulati P, Yeo GS. The biology of FTO: from nucleic acid demethylase to amino acid sensor. Diabetologia. 2013;56(10):2113-21. doi: 10.1007/s00125013-2999-5.

54. Cota D, Proulx K, Smith KA, Kozma SC, Thomas G, Woods SC, Seeley RJ. Hypothalamic mTOR signaling regulates food intake. Science. 2006; 312(5775):927-30. doi: 10.1126/science.1124147.

55. Ragvin A, Moro E, Fredman D, Navratilova P, Drivenes $\varnothing$, Engström PG Alonso ME, Mustienes EC, Skarmeta JLG, Tavares MJ, Casares F, Manzanares M, van Heyningen V, Molven A, Njølstad PR, Argenton F, Lenhard B, Becker TS. Long-range gene regulation links genomic type 2 diabetes and obesity risk regions to HHEX, SOX4, and IRX3. Proc Natl Acad Sci. 2010;107(2):77580. doi: 10.1073/pnas.0911591107.

56. Smemo S, Tena JJ, Kim K-H, Gamazon ER, Sakabe NJ, Gomez-Marin C, Aneas I, Credidio FL, Sobreira DR, Wasserman NF, Lee JH, Puviindran V, Tam D, Shen M, Son JE, Vakili NA, Sung H-K, Naranjo S, Acemel RD, Manzanares M, Nagy A, Cox NJ, Hui C-C, Gomez-Skarmeta JL, Nobrega MA. Obesityassociated variants within FTO form long-range functional connections with IRX3. Nature. 2014;507(7492):371-5. doi: 10.1038/nature13138. http://www. nature.com/nature/journal/v507/n7492/abs/nature13138. htmllssupplementary-information

57. Wu Q, Saunders RA, Szkudlarek-Mikho M, Idl S, Chin K-V. The obesityassociated Fto gene is a transcriptional coactivator. Biochemical and Biophysical Research Communications. 2010;401(3):390-5. doi: 10.1016/j. bbrc.2010.09.064.

58. Guo J, Ren W, Li A, Ding Y, Guo W, Su D, Hu C, Xu K, Chen H, Xu X, Yang T, Jia W. Fat mass and obesity-associated gene enhances oxidative stress and lipogenesis in nonalcoholic fatty liver disease. Dig Dis Sci. 2013;58(4):1004-9. doi: 10.1007/s10620-012-2516-6.

59. Bravard A, Vial G, Chauvin MA, Rouille Y, Bailleul B, Vidal H, Rieusset J. FTO contributes to hepatic metabolism regulation through regulation of leptin action and STAT3 signalling in liver. Cell communication and signaling : CCS. 2014;12:4. doi: 10.1186/1478-811x-12-4.

60. Guan L, Shang XR, Liu FH, Song JY, Ma J, Wang HJ. Association of INSIG2 rs9308762 with ALT level independent of BMI. J Pediatr Gastroenterol Nutr. 2014;58(2):155-9. doi: 10.1097/MPG.0b013e3182a87b71.

\section{Submit your next manuscript to BioMed Central and we will help you at every step:}

- We accept pre-submission inquiries

- Our selector tool helps you to find the most relevant journal

- We provide round the clock customer support

- Convenient online submission

- Thorough peer review

- Inclusion in PubMed and all major indexing services

- Maximum visibility for your research

Submit your manuscript at www.biomedcentral.com/submit
Biomed Central 